\title{
Spatio-temporal rainfall variation and stock management in arid Namibia
}

\author{
DAVID WARD, DAVID SALTZ, AND BEN T. NGAIRORUE
}

Authors are Professor, Department of Conservation Ecology, University of Stellenbosch, Matieland 7602, South Africa, Senior Lecturer, Mitrani Department for Desert Ecology, Jacob Blaustein Institute for Desert Research, Ben Gurion University of the Negev, Sede Boqer 84990, Israel, and Research Student, Desert Research Foundation of Namibia, 7 Rossini Street, Windhoek, Namibia.

\section{Abstract}

The high inherent variability in rainfall and forage availability in arid regions makes it very difficult for a rancher to establish a herd size that is suited to the environment and also complicates management decision-making regarding the distribution of animals within and between areas of a single ranch. We recorded the temporal and spatial variability in rainfall and grass production on a local scale on 3 ranches in arid Namibia over 3 years, to determine their effects on potential stocking density, stock movement decisions and timing of grazing. We conducted a 3-year experiment to test the effects of the timing of grazing on grass regrowth. Furthermore, we tested the reliability of a rule-ofthumb used by ranchers to ascertain whether a drought year is likely and whether they should sell some of their cattle in advance of drought. We expanded the scale of the study to include 31 ranches over a $700 \mathrm{~km}$-long rainfall gradient to determine the reliability of extrapolating conclusions obtained at a local scale to a larger geographic scale. We found that rainfall and grass production varied widely, resulting in recommended stocking densities up to $\mathbf{1 0}$-fold smaller than those currently recommended by the Namibian Ministry of Agriculture. We found that there is no optimal spatial or temporal scale of ranch management, and that ranchers could do no better than a simple rule of "move the cattle to wherever there is most grass". This simple rule's validity was reinforced by the results of our experiment, which showed that there was no significant effect of timing of grazing on grass regrowth. Statistical analyses of long-term rainfall records indicated that the ranchers' rule-of-thumb regarding approaching drought was unreliable and that this could lead to substantial loss of profit if adhered to.

Key Words: variability, ranching, drought, range management, grass production, arid environments, desert, Africa

This study was funded by grant no. TA-MOU-94-C13-149 by the U.S. Agency for International Development to David Ward, Uriel Safriel and Mary Seely. We thank Iris Musli, Vilho Mtuleni, Lilo Nghinanwame, and Shimrit Ginott-Lahav for assistance in the field. This is publication number 410 of the Mitrani Department for Desert Ecology and publication number 159 of the Ramon Science Center. The Ramon Science Center receives funding from the Israeli Ministry of Science and the Local Council of Mizpe Ramon.

Manuscript accepted 14 Jun. 03.

\section{Resumen}

La alta variabilidad inherente en la lluvia y la disponibilidad de forraje en regiones áridas hace muy dificil para los rancheros establecer un tamaño de rebaño que se ajuste al ambiente y además complica la toma de deciciones sobre el manejo referente a la distribución de animales dentro y entre áreas de un único rancho. En este estudio, registramos la variabilidad temporal y espacial en la lluvia y producción de pastos en una escala local en tres ranchos en la Namibia árida a lo largo de tres años, para determinar sus efectos en la densidad potencial de la ganadería, las decisiones de movimiento de ganado y el tiempo de pastoreo. Realizamos un experimento de tres años para probar el efecto del pastoreo en el rebrote de pastos. Además, probamos la veracidad de "la regla del pulgar" usada por rancheros para acertar sí es probable un año de sequía y sí ellos deben vender algunas de sus reces antes de la sequía. Expandimos la escala de el estudio para incluir 31 ranchos sobre unos $700 \mathrm{~km}$ a lo largo de un gradiente de lluvia para determinar la veracidad de extrapolar conclusiones obtenidas a una escala local a una escala geográfica mayor. Encontramos que la lluvia y la producción de pastos varía ampliamente, resultando en densidades de ganadería recomendadas hasta diez veces más pequeñas que las recomendadas actualmente por el Ministerio de Agricultura en Namibia. Encontramos que no hay una escala espacial o temporal óptima para el manejo del rancho, y que los rancheros no pueden hacer mejor que una simple regla de "mover las reces a donde hay la mayor cantidad de pastos". Esta simple validez de la regla fue reenforzada por el resultado de nuestro experimento, el cual muestra que no había un efecto significativo de el tiempo de pastoreo en el rebrote de pastos. El análisis estadístico de los registros de la lluvia a largo término indican que "la regla del dedo pulgar" de los rancheros referente a la llegada de la sequía fue no verídica y que esto puede conllevar a perdidas substanciales de ganancias si la obedece.

Overgrazing is frequently considered to be the major source of land degradation in arid parts of Africa (see e.g. Acocks 1953, Jarman and Bosch 1973, Sinclair and Fryxell 1985, Schlesinger et al. 1990, Dean and McDonald 1994, Quan et al. 1994, Middleton and Thomas 1997). However, several authors have contended that rainfall in arid regions is the major driving variable and has the ability to "recharge" a system that suffers heavy grazing pressure (Ellis and Swift 1988, Tapson 1993, Werner 1994, Sullivan 1996). Indeed, high temporal and spatial variation in rainfall is characteristic of arid areas (see e.g. Sharon 1972, 1981, Evenari 
et al. 1982), which results in arid grazing ecosystems that are non-equilibrial, eventdriven systems (see e.g. O'Connor 1985, Venter et al. 1989, Milchunas et al.1989, Behnke and Abel 1996, Parsons et al. 1997). Indeed, it is generally agreed that where pastoralists are able to maintain their activities on a large spatial scale by migrating to areas where key rich resources can be exploited, negative effects of grazing on plant biodiversity do not develop (Sinclair and Fryxell 1985, Ellis and Swift 1988, Behnke and Abel 1996). Moreover, even where pastoralists are forced to settle in small areas, abiotic variables such as precipitation may be of such over-riding importance that these negative effects of grazing can not be detected (see e.g. O'Connor 1985, Archer et al. 1989, Tapson 1993, Scoones 1995, Ward et al. 1998, 2000a, 2000b).

The high inherent variability in grass production in arid regions makes it very difficult for the rancher to establish a herd size that is suited to the capacity of the environment to sustain these animals and also complicates management decisionmaking regarding the distribution of animals within and between areas of a single ranch. Indeed, informal surveys conducted by us in arid Namibia indicate that ranchers find that they are overgrazing their land even when they comply with the stocking densities recommended by agricultural extension officers. Clearly, there is much still to be learned about the nature of the temporal and spatial variability in rainfall and how it affects the production of natural forage.

We recorded the spatial and temporal variation in rainfall and grass production on 32,000 ha on 3 contiguous commercial ranches in an arid area of central Namibia and attempted to ascertain how this variability affects management decisions made by ranchers and how, if at all, current management strategies could be improved upon. To determine the generality of the results obtained at this local scale, we also examined the effects of temporal and spatial variation in rainfall on grass production, over a $700 \mathrm{~km}$-long gradient on 31 commercial ranches from south to north in Namibia.

\section{Management decisions pertaining to arid Namibian ranches}

Some of the most important stock management options available to ranchers in arid Namibia include:

Stocking density.- Rangeland capacity calculations in Namibia are conventionally made on the basis of the relationship between grass biomass and mean annual rainfall of the region, with the assumption that livestock eat a mean amount of grass (which is related to body mass) each day. This is known as the "biomass" concept of grazing capacity (Bester 1995). Empirical data indicate that an average cow in Namibia weighs $450 \mathrm{~kg}$ and eats $3 \%$ of her mass in grass per day (Van Schalkwijk 1978, Bester 1995). Through division of this intake rate into total grass biomass/ha, one can calculate stocking capacity. However, because there is often a negative correlation between the mean and variability in rainfall quantities, the scale over which such estimates are valid varies widely. The current method of ascertaining stocking density in Namibia uses a regionwide stocking density calculation (see Van der Merwe 1983) based on mean annual rainfall in consecutive $100 \mathrm{~mm}$ isohyets. Because this estimation ignores the negative correlation between the mean and the variance in rainfall, it may be a very imprecise way of determining stocking density. Based on the biomass concept, we calculated stocking density over a grid of 14 raingauges on 32,000 ha of 3 ranches to ascertain the reliability of measurements made on the basis of a single regional mean annual rainfall value.

Where to move stock.- By 1958, several experimental ranches in Namibia started studies using different multi-paddock and continuous grazing systems (Bester 1995). As a result of this research, a 4-paddock per herd system was adopted by many ranchers. In this system, the growing season was subdivided into several periods, allowing an early summer, a late summer, and a winter grazing period while 1 paddock was rested for the full growing season (Rowland 1974). This system allowed perennial plants a rest period to recover lost resources. However, there are a number of cases where ranchers with a single paddock, continuous grazing strategy do as well as those using the multi-paddock system (Bester 1995). A continuous grazing system is less labor intensive and far cheaper than a multi-paddock system due to the reduced need for fencing. Until 1990, when Namibia was still under South African control, ranchers were offered financial incentives to erect fences because of the perceived benefits for agricultural production. However, since 1990, such incentives have been cancelled and many ranchers question whether the purported benefits of multi-paddock systems outweigh the substantial increased costs.

We measured the amount of grass available monthly over a grid covering 3 ranch- es to determine whether there was an appropriate spatial scale over which ranches should be managed. Finding such a scale would allow the rancher to manage sub-sections of the ranch in a manner that is suitable to the amount of stock that can reasonably be maintained on each section and would contribute to the understanding of the relative benefits of continuous grazing vs. multi-paddock systems in these arid conditions.

When to graze particular parts of the ranch.- Conventional wisdom and some empirical data (e.g. Danckwerts and Stuart-Hill 1987, Danckwerts 1993) dictates that grazing in the wet season has a greater negative effect on grasses than grazing in the dry season because the above-ground portions of the grass are dead in the dry season and thus no negative feedback effect occurs on the plant's resources (Hoffman 1997). This rationale is clearly related to the use of multi-paddock systems outlined above. Following this reasoning, heavy stocking in the dry season is of little consequence, while wetseason grazing needs careful monitoring to prevent depletion of plant resources.

An additional management consideration in terms of moving stock in central Namibia is the use of mountains as grazing land. Ranchers frequently use the mountains for grazing immediately after the rains (rainy season = September-March) but bring the animals down in the dry season because of the logistic difficulties involved in getting the animals to water. Also, losses to hyaenas Crocuta crocuta and occasionally lions Panthera leo are significant in the unguarded mountain regions. For example, one of the farmers in this study lost 17 cows to hyaenas in a single year. We designed an experiment to test the effects of dry and wet season grazing on grass production on the above-mentioned ranches.

When to sell animals in a drought.- The most obvious response to drought conditions is to sell some of the herd to reduce pressure on the plant resources and to maintain condition of the remaining animals, in particular that of the breeding nucleus. The high inherent variability in the spatial and temporal distribution of rainfall frequently confounds ranchers' attempts at finding a reliable way to decide early on in the growing season whether the entire season will be dry to pre-empt the negative impacts of a large herd on the grazing resource. Ranchers in Namibia have a common rule of thumb when it comes to selling animals in times of drought. This rule states that "if rains 
are poor by December, then sell $33 \%$ of your animals because it is likely to be a drought year". We performed statistical analyses on long-term rainfall records available from a number of sites in Namibia to determine the reliability of this rule. We wished to determine whether a dry early season (September-December) is likely to indicate a drought year overall.

\section{Methods}

\section{Study ranches}

\section{(i) Local-scale study}

Three contiguous ranches arranged along a north-south rainfall gradient were studied in central Namibia (Fig. 1). The rainfall gradient runs from $80-180 \mathrm{~mm}$ per annum. The vegetation follows a savanna to grassland transition along this gradient. All ranches have sandy soil on a single rock type, schist, minimizing possible variation in grass production due to a heterogeneous soil layer. The 3 ranches lie in a north-south running valley and are flanked on either side by parallel mountain ridges. The northernmost ranch, Quabis $\left(22^{\circ} 50^{\prime} \mathrm{S}, 15^{\circ} 55^{\prime} \mathrm{E}\right)$, is 7,000 ha in size and has a mean \pm S.E. long-term rainfall of $160 \pm 44 \mathrm{~mm}$. The central ranch, Tweespruit $\left(22^{\circ} 55^{\prime} \mathrm{S}, 15^{\circ} 55^{\prime} \mathrm{E}\right)$, is 5000 ha in size and has a mean \pm S.E. long-term rainfall of $122 \pm 35 \mathrm{~mm}$, and the southern ranch, Changans $\left(23^{\circ} 00^{\prime} \mathrm{S}, 15^{\circ} 55^{\prime} \mathrm{E}\right)$, is 20,000 ha in extent and has a mean \pm S.E. long-term rainfall of $101 \pm 32 \mathrm{~mm}$.

\section{(ii) Large-scale study}

The rainfall gradient in Namibia runs approximately from north to south. Thus, for the large-scale study, we chose 10 or 11 ranches within $100 \mathrm{~km}$ radius of each of the following towns/cities arranged along this gradient (Fig. 2) where longterm rainfall data (approx. 100 years) were available: Otjiwarongo (north; mean annual rainfall $=450 \mathrm{~mm} ; \mathrm{c} . \mathrm{v}$. $=0.34$ ), Windhoek (central; mean annual rainfall = $361 \mathrm{~mm}$; c.v. $=0.39$ ) and Keetmanshoop

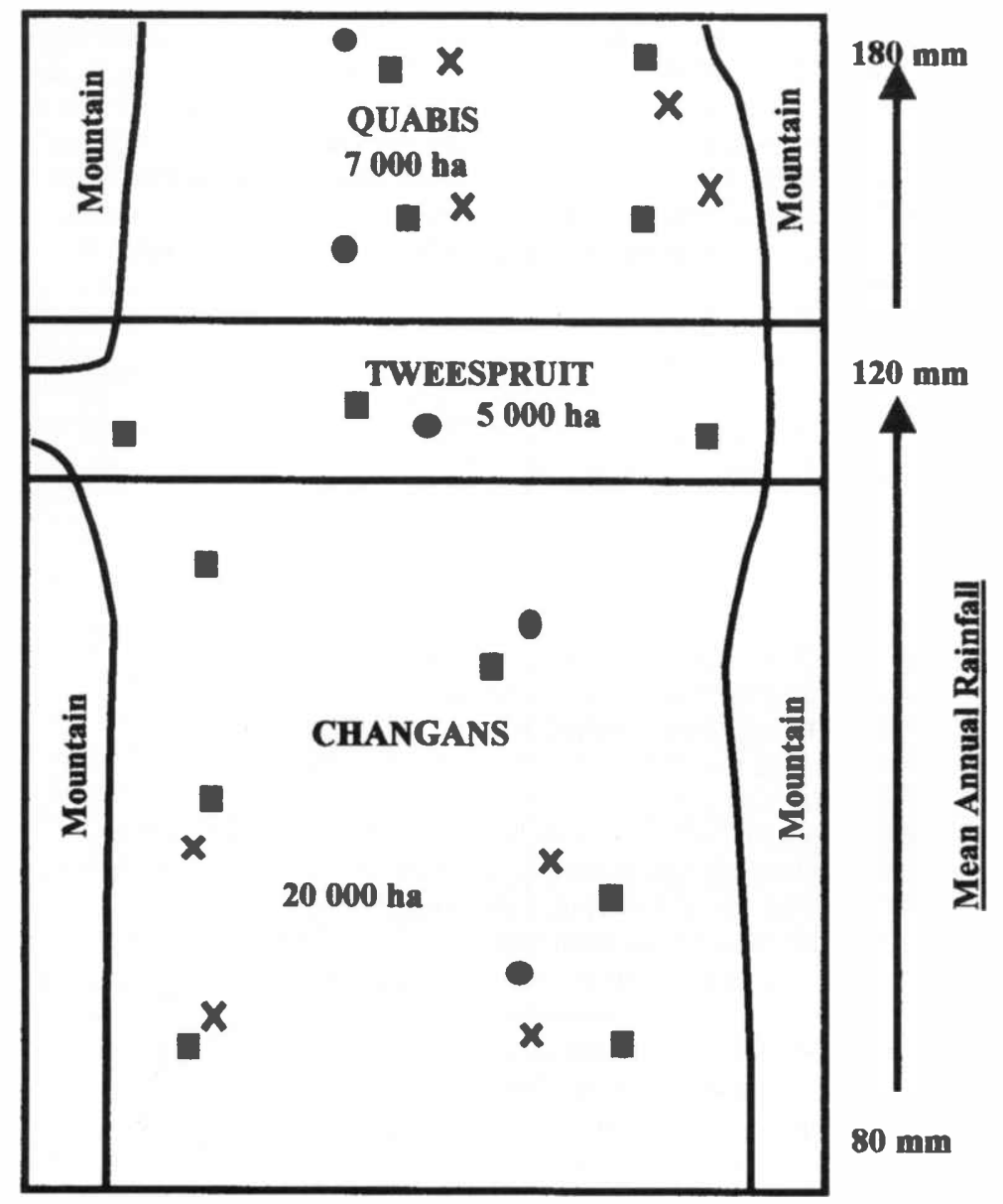

Fig. 1. Schematic map of the ranches Quabis, Tweespruit and Changans in central Namibia. Squares indicate the position of the 14 raingauges, circles indicate the position of the exclosures and $\mathrm{X}$ indicates the position of the grass-clipping plots.

(south; mean annual rainfall $=158 \mathrm{~mm}$; c.v. $=0.66$ ). These ranches were chosen randomly with the stipulation that at least 10 consecutive years of rain data were available for each ranch. Mean \pm S.E. annual rainfall on the northern ranches was $388 \pm 17 \mathrm{~mm}$, in the central region was $183 \pm 26 \mathrm{~mm}$, and in the south was $141 \pm 13 \mathrm{~mm}$. We collected stocking data from the ranchers for the 1996-1997 season and obtained medium-term stocking data (for the 10 years prior to this season) from the Namibian Directorate of Veterinary Services. All stocking values were converted to Large Stock Units (LSU's) per hectare, following Meissner et al. (1983).

\section{Rainfall}

We measured monthly rainfall at 14 raingauges distributed approximately equidistantly along the length of the rainfall gradient on the ranches Quabis, Tweespruit and Changans from October 1995 until September 1998. Long-term rainfall data were obtained for the 31 ranches in the large-scale study from the Namibian Weather Bureau.

\section{Grass biomass and height}

We measured grass biomass within a $100 \mathrm{~m}$ radius of each of the 14 raingauges on Quabis, Tweespruit and Changans monthly from October 1995 until September 1998. All of these sites were situated on the plains. A further 2 sites were situated in the mountains on the eastern and western sides of these ranches. Grass was clipped to ground level within a $1 \mathrm{~m}^{2}$ frame, dried and weighed. Eight subsamples of grass were taken within a 100 $m$ radius by random positioning of the frame at each site (=replicate) each month. The optimal number of subsamples per site was determined in a pilot study in which we plotted the coefficient of variation in grass biomass against the cumulative number of subsamples. The mean number of subsamples (across sites) at which the asymptotic coefficient of variation was reached was chosen as the level of subsampling per site.

For the large-scale study on the 31 ranches, we measured mean grass height using a point-frequency frame at the end of the wet season of 1997. The frame is made from aluminium and is $1 \mathrm{~m}$ high and $1 \mathrm{~m}$ long, has 10 guide holes bored perpendicular through the 2 horizontal fixed bars (Mueller-Dombois and Ellenberg, 1974). A steel rod of the same length as the legs is slid through the holes which are equally spaced, $10 \mathrm{~cm}$ apart, along the linear frame. 


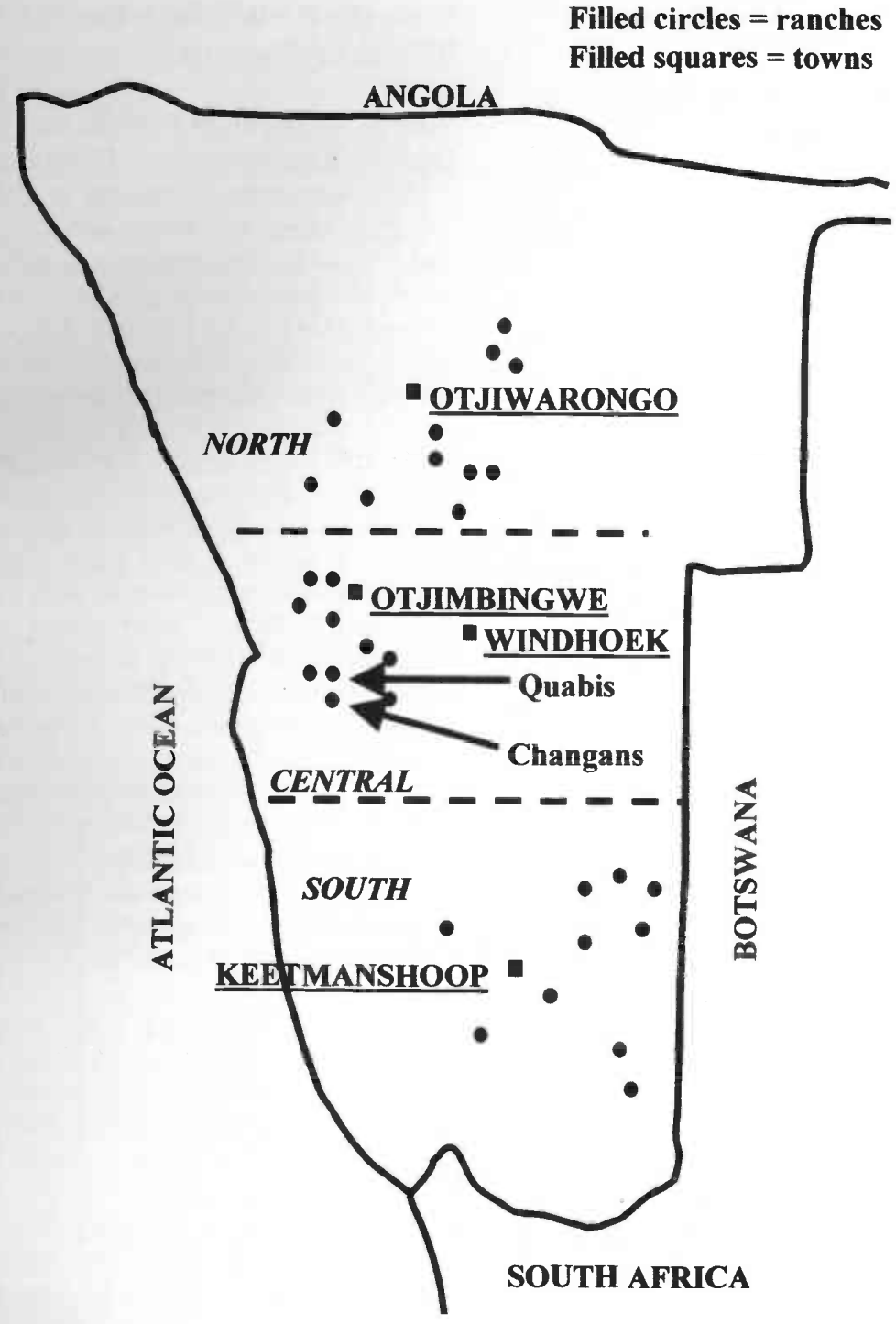

Fig. 2. Schematic map of the 31 ranches in the large-scale study and the position of the cities and towns (squares) mentioned in the text.

The point-frequency frame is placed with its legs over the vegetation to be measured and the pins are lowered vertically one after the other. Wherever the pin touches the vegetation the height is recorded. We took the mean of each placement of the frame as a single data point in our analyses to avoid pseudoreplication. This provides a measure of percentage cover for the species that are intercepted by pins, as well as the mean grass height (Mueller-Dombois and Ellenberg 1974).

The high spatial and temporal variance in plant cover, biodiversity and soil quality in arid ecosystems makes comparisons of the effects of grazing on plant biodiversity across habitats and ecosystems rather complex. For this reason, many researchers have emphasized comparisons in the piosphere, the region of heavy grazing around watering points (James et al. 1999). Clearly, animals in arid ecosystems are limited by the availability of water and hence tend to collect there. As a result, these are usually the most heavily damaged areas in a ranching ecosystem. To make unbiased comparisons across ranches, we sampled grass along a $1000 \mathrm{~m}$ transect starting at the most active watering point on each ranch. Three placements of the frame $20 \mathrm{~m}$ apart were done at 100 , $200,300,500$, and $1,000 \mathrm{~m}$ from each watering point. At each point, we also collected soil samples for analysis of organic carbon, total nitrogen, phosphorus, conductivity, $\mathrm{pH}$ and water-holding capacity (for further details, see Ward et al. 1998). Ranches with good grass production should have both a greater mean and steeper slope of grass height with increasing distance from the watering point.
Plant cover and species richness near and far from watering points

To determine whether stocking levels on the study ranches have significant negative impacts on the vegetation, we used McAuliffe's (1990) log-series survey method to record percentage cover, species richness and species diversity of perennial plants in a total of 39 plots on Quabis, Tweespruit, and Changans ranches in September 1995. This method has proved to be one of the most effective means of recording semi-desert and desert vegetation (Ward and Olsvig-Whittaker 1993, Ward et al. 1993). We used a plot radius of $12.9 \mathrm{~m}$. We surveyed annual and perennial grasses within these plots using a point intercept method.

\section{Exclosures}

We erected five, $20 \mathrm{~m} \mathrm{X} 20 \mathrm{~m}$ exclosures equidistantly along the length of the north-south axis of the farms in January 1996 to compare the amount of grass growing inside to that eaten by stock outside the exclosures. These exclosures were $3 \mathrm{~m}$ high and excluded all large mammalian herbivores. In March 1998 at the end of the wet season, we measured grass height inside and outside the exclosures using a point-frequency frame. Twenty placements of the frame at random were used to measure grass height in each plot.

\section{Grass-cutting experiment}

To simulate the effects of grazing in different seasons, we conducted an experiment on Quabis and Changans ranches. Four sets of plots were set up on each ranch. Within each set, one plot was randomly assigned as a control (non-clipped), one as dry-season clipped and one as wetseason clipped. Dry-season clips were conducted in October each year and wetseason clips in March. Each plot was $10 \mathrm{~m}$ $\mathrm{X} 10 \mathrm{~m}$ in size. The experiment ran from October 1995 until March 1998. Final grass height on each plot was recorded in September 1998.

\section{Vegetation community analyses}

We used detrended correspondence analysis (DECORANA) for the analysis of differences between perennial plant communities near and far from water. DECORANA is an improved multivariate eigenvector technique based on reciprocal averaging (also called' correspondence analysis') but correcting its main faults (Hill and Gauch 1980). The DECORANA pro- 
gram is an effective and objective means of summarizing data on plant presence and abundance into one or more composite dimensions (axes) that represent the overall relationships among plant communities (Hill and Gauch 1980).

\section{Spatial analyses}

We used Mantel tests to determine whether there was a significant correlation between the similarity in rainfall/grass between any pair of sites and the geographic distance between them. We used semivariograms to determine if there was an appropriate spatial scale of variance in rain and grass distributions. Semivariograms plot the semivariance of measured parameters against the distance between sites (Davis 1986). Semivariance $\left(\gamma_{h}\right)=$ $\sum\left(x_{i}-x_{i+h}\right) / 2 n$, where $x_{i}=$ measurement at site $i$ and $\mathrm{x}_{\mathrm{i}+\mathrm{h}}=$ another measurement taken at distance $h$ from $i$. The number of sites is $\mathrm{n}$, so the number of comparisons between pairs of sites is $n$ - $h$. Typically, semivariance increases from the origin with increasing distance between sites until an asymptote is reached at which the semivariance $=$ variance, $\sigma^{2}$ (Davis 1986). The point at which the asymptote, a, is reached on the $x$ axis is half the spatial scale at which appropriate management decisions should be made because this is the scale at which variation in the abiotic phenomena (in this case, rainfall) acts. Should the regression of semivariance against distance increase across the entire range of measured inter-site distances without reaching an asymptote, this indicates that the scale of variation is greater than that of the study area. Conversely, should the regression line run parallel to the abscissa across the entire ranges of inter-site distances, this indicates that the scale of variation is smaller than the minimum inter-site distance measured and that variation over the measured inter-site distances is ostensibly random.

Kriging was used to extrapolate contours of equal stocking density on the basis of grass biomass measurements near each of the 14 raingauges mentioned above. Kriging provides a means of interpolating values for points not physically sampled using knowledge about the underlying spatial relationships in a data set (Davis 1986). Semivariograms provide this knowledge. Kriging is based on regionalized variable theory and provides an optimal interpolation estimate for a given coordinate location, as well as a variance estimate for the interpolation value.

\section{Results}

\section{Temporal variation in rainfall on} Quabis, Tweespruit and Changans

Mean annual rainfall differed considerably among years. Mean \pm S.E. rainfall across the 14 raingauges in the 1995-1996 season was $59 \pm 8 \mathrm{~mm}$, in the 1996-1997 season was $124 \pm 16 \mathrm{~mm}$, and in 1997-1998 was $85 \pm 8 \mathrm{~mm}$. The correlation in rainfall between sites across years was significant for the 1995-1996 vs. 1996-1997 comparison $(r=0.76, F=$ $16.701, P=0.002$, error d.f. $=12$ ), but not for the 1995-1996 vs. 1997-1998 comparison $(\mathrm{F}=1.475, \mathrm{P}=0.248$, error d.f. $=12)$ or the 1996-1997 vs. 1997-1998 comparison $(F=1.802, P=0.204$, error d.f. $=12)$.

There was a significant positive correlation between grass mass averaged over months and average seasonal rainfall across sites $(r=0.58, F=6.161, P=0.029$, error d.f. $=12$ ).

\section{Spatial variation in rainfall on Quabis, Tweespruit and Changans}

There were large differences in rainfall and grass biomass between sites (Fig. 3a and $3 b)$. There was neither a significant correlation between monthly rainfall and distance between sites (Mantel test: $r=$ $0.02, \mathrm{P}=0.609,999$ permutations) nor between grass biomass $/ \mathrm{m}^{2}$ and distance between sites (Mantel test: $\mathrm{r}=-0.10, \mathrm{P}=$ $0.792,999$ permutations). Similarly, semivariograms show no pattern in seasonal rainfall or mean grass biomass at the end of the wet season in all 3 years (Fig. 4a$4 \mathrm{f})$. The results are consistent with a random distribution of rainfall and grass across sites. Thus, there is no single appropriate spatial scale for management of stock movements.
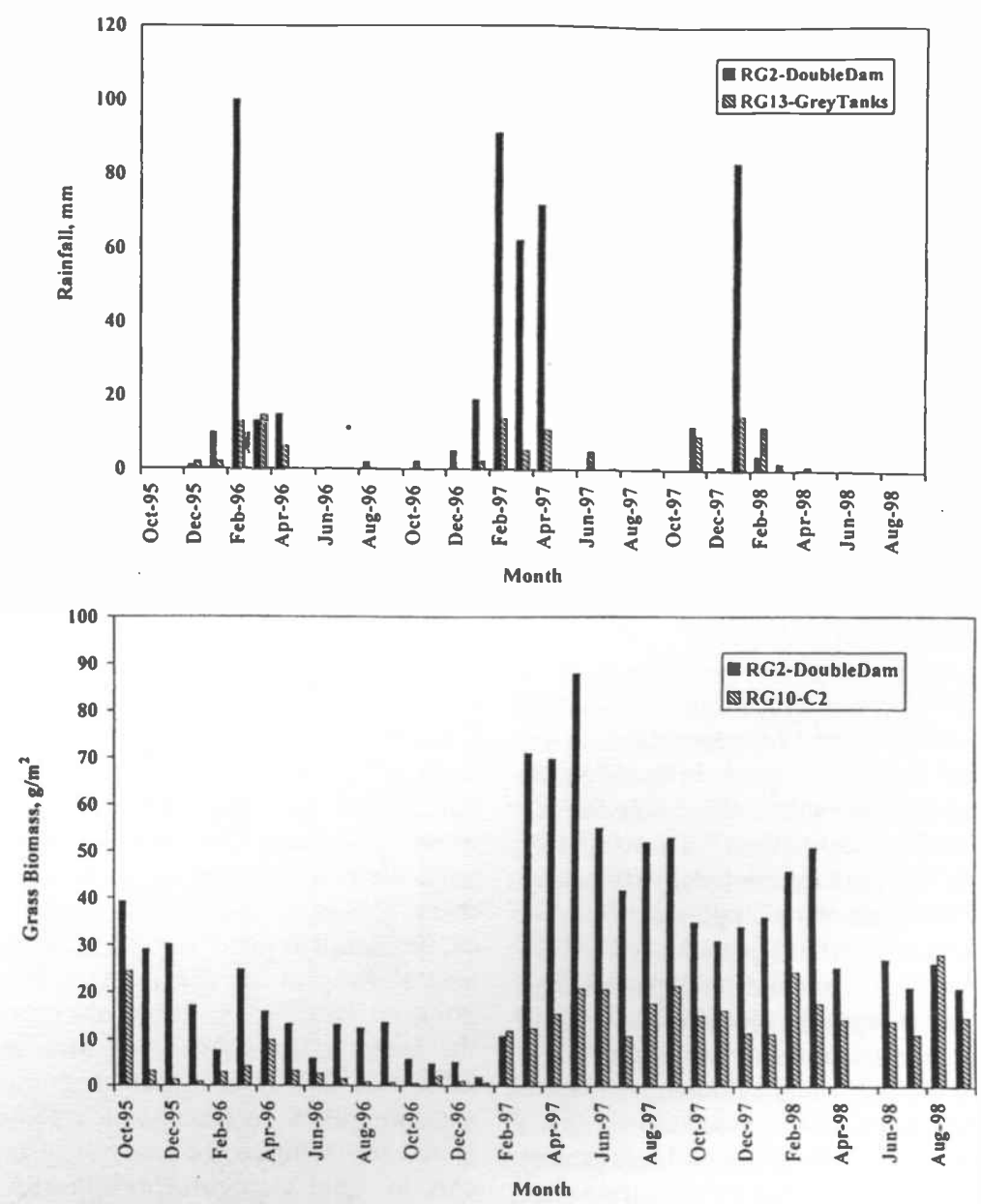

Fig. 3. a. Histogram indicating monthly rainfall at the 2 extreme raingauges during the 3year study. Double Dam is on Quabis ranch and Grey Tanks on Changans ranch.

b. Histogram indicating mean monthly grass biomass $/ \mathrm{m}^{2}$ at the 2 extreme grass sites during the 3-year study. 
Rainfall and vegetation correlations with altitude on Quabis, Tweespruit and Changans

There was a significant positive correlation between average seasonal rainfall and altitude $(\mathrm{r}=0.75, \mathrm{~F}=15.603, \mathrm{P}=0.002$, error d.f. $=12$ ). There was a significant positive correlation between mean grass biomass and altitude $(r=0.53, \mathrm{~F}=4.778$, $\mathrm{P}=0.049$, error d.f. $=12$ ). Plant species richness in McAuliffe plots was also significantly correlated with altitude $(r=$ $0.53, \mathrm{~F}=14.448, \mathrm{P}<0.001$, error d.f. $=$ 37). Contrastingly, percentage plant cover in McAuliffe plots was not significantly correlated with altitude $(\mathrm{F}=2.676, \mathrm{P}=$ 0.110 , error d.f. $=37$ ).

\section{Effects of grazing on grass inside} and outside exclosures on Quabis, Tweespruit and Changans

We found a strong positive correlation between grass biomass $/ \mathrm{m}^{2}$ and mean grass height $(\mathrm{r}=0.87, \mathrm{~F}=40.59, \mathrm{P}<0.001$, error d.f. $=13$ ) at Otjimbingwe in the central region of our study. The best-fit regression equation is: Grass Biomass $\left(\mathrm{g} / \mathrm{m}^{2}\right)=0.181 *$ Mean Grass Height $(\mathrm{cm}) \pm$ 4.746 .

There was a highly significant difference in mean \pm S.E. grass height between sites inside $(4.8 \pm 0.3 \mathrm{~cm})$ and outside exclosures $(3.6 \pm 0.3 \mathrm{~cm})$ in March 1998 $(F=7.640, p=0.006$, error d.f. $=44)$ (Fig. $5)$. Noteworthy is the single exclosure in which the mean value is lower than that outside it, indicating the effects of either herbivory by termites or abiotic factors inside the exclosure.

Plant cover and species richness near and far from watering points on Quabis, Tweespruit and

\section{Changans}

There was no significant difference in plant species richness near $(6.1 \pm 0.4$ species per plot $)$ and far $(6.6 \pm 0.4$ $\mathrm{spp} . / \mathrm{plot})$ from water $(\mathrm{F}=0.754, \mathrm{p}=$ 0.391 , d.f. $=37$ ) in September 1995. Similarly, there was no significant difference in the percentage plant cover in plots near $(34 \pm 5 \%)$ and far $(30 \pm 2 \%)$ from watering points $(\mathrm{F}=0.662, \mathrm{P}=0.421$, error d.f. $=37$ ).

We used DECORANA to compare vegetation community structure between sites near and far from watering points. The percentage of variance explained by the first 2 axes in the DECORANA was low $(\mathrm{DC} 1=18.9 \%, \mathrm{DC} 2=8.4 \%)$. There was no significant correlation between $\mathrm{DCl}$ a) Semivariogram of rainfall vs. distance 1995-1996 season

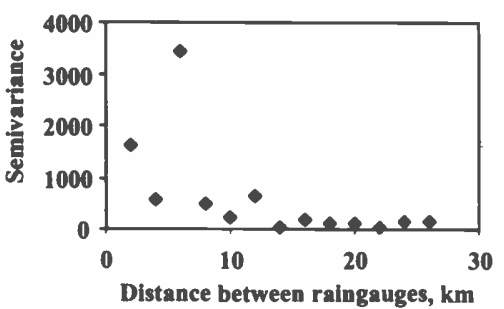

c) Semivariogram of rainfall vs. distance 1996-1997 season

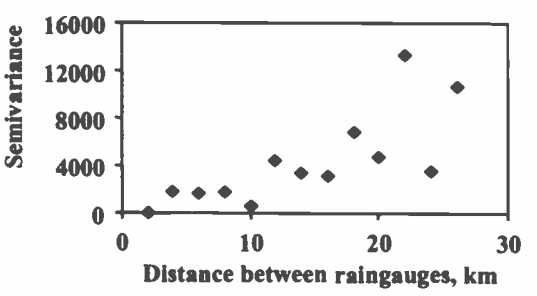

e) Semivariogram of rainfall vs. distance 1997-1998 season
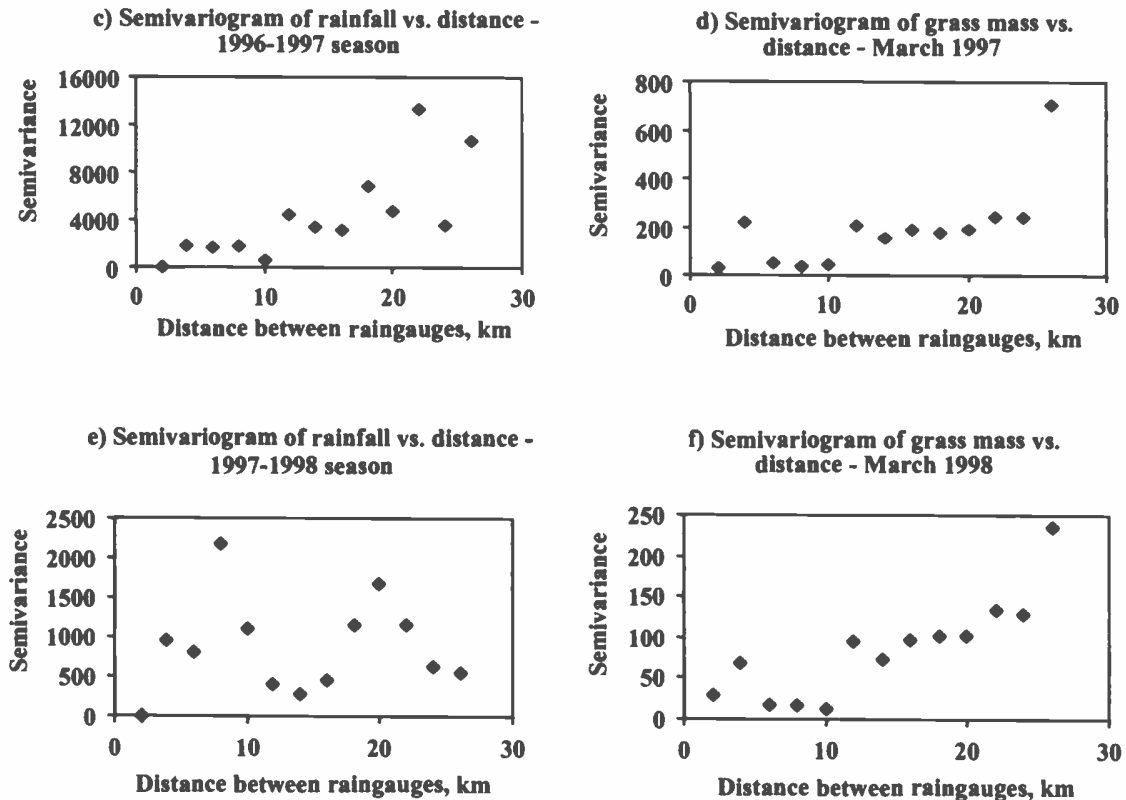

f) Semivariogram of grass mass vs. distance - March 1998

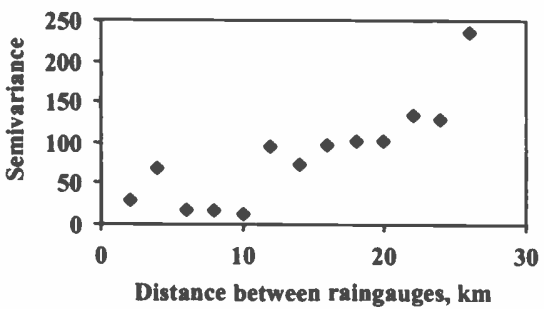

Fig. 4. a. Semivariogram of rainfall in the 1995-1996 season.

b. Semivariogram of mean monthly grass biomass $/ \mathrm{m}^{2}$ in the $1995-1996$ season.

c. Semivariogram of rainfall in the 1996-1997 season.

d. Semivariogram of monthly grass biomass $/ \mathrm{m}^{2}$ in the $1996-1997$ season.

e. Semivariogram of rainfall in the 1997-1998 season.

f. Semivariogram of monthly grass biomass $/ \mathrm{m}^{2}$ in the $1997-1998$ season.

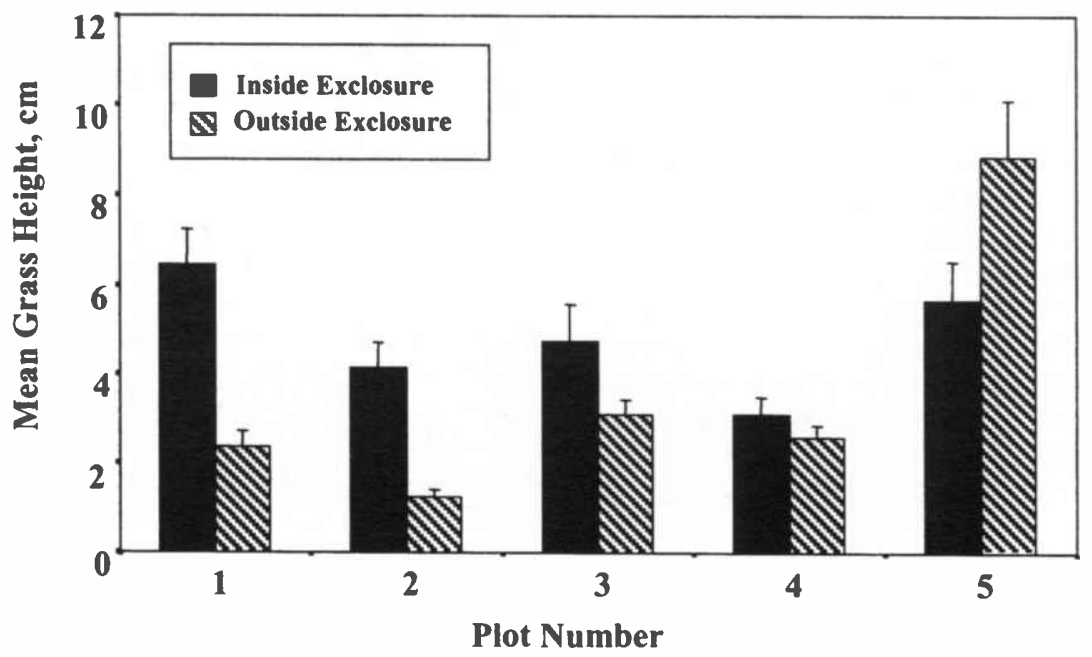

Fig. 5. Mean \pm S.E. grass height inside and outside exclosures in March 1998 . 
values and altitude $(\mathrm{F}=1.337, \mathrm{P}=0.255$, error d.f. $=37$ ), although there was a highly significant positive correlation between DC2 values and altitude $(r=0.42, F=$ 7.750, $\mathrm{P}=0.008$, error d.f. $=12$ ). We found a highly significant difference in DC1 values between sites near and far from watering points $(t=2.962, P=0.006$, d.f. $=35$ ). There was no significant difference in DC2 values between sites near and far from the watering points $(t=0.893, P$ $=0.378$, d.f. $=35$ ). Together these results indicate that the most important axis in this ordination $(\mathrm{DCl})$ is primarily a grazing intensity axis while DC2 is correlated with altitude (which is correlated with rainfall (see above)) (Fig. 6).

\section{Large-scale study on 31 ranches}

Seasonal rainfall on these ranches in the year in which we conducted this study (1997) did not differ significantly from the long-term mean (paired t-test: $\mathrm{t}=0.524, \mathrm{P}$ $=0.604$, d.f. $=30$ ). Mean \pm S.E. rainfall in the $1996 / 1997$ season was $232+30 \mathrm{~mm}$, while the long-term mean \pm S.E. rainfall on these ranches was $240 \pm 22 \mathrm{~mm}$.

There was a significant negative correlation between the coefficient of variation in annual rainfall and median annual rainfall across all sites $(r=0.97, F=92.678, P<$ 0.001 , error d.f. $=6$ ). There was no significant correlation between the coefficient of determination in annual rainfall between pairs of ranches and the geographic distance between them in any of the 3 regions of Namibia (Mantel tests: north $-\mathrm{r}=$ $-0.372, \mathrm{P}=0.994$; central $-\mathrm{r}=-0.043, \mathrm{P}=$ 0.590 ; south $-r=-0.076, P=0.659 ; 999$ permutations used in all tests). Mean \pm S.E. coefficient of determination in rainfall between pairs of farms was low in all regions: in the north was $0.47 \pm 0.02$, in the central region was $0.32 \pm 0.03$, and in the south was $0.33 \pm 0.04$.

We ran a multiple linear regression between mean grass height and mean annual rainfall, a number of soil quality variables (organic carbon, water-holding capacity, nitrogen, phosphorus, $\mathrm{pH}$, conductivity) and the short-term and mediumterm (11 years) stocking densities. There was a significant positive correlation between grass height and these variables ( $\mathrm{r}$ $=0.87, \mathrm{~F}=6.002, \mathrm{P}<0.001$, error. d.f. $=$ 20). However, of all these independent variables, rainfall only had a significant effect $(t=5.457, P<0.001)$. A simple linear regression of mean grass height per ranch on mean annual rainfall was highly significant $(r=0.81, F=52.41, P<0.001$, error d.f. $=29$ ). There was also a significant, although weaker, positive correlation

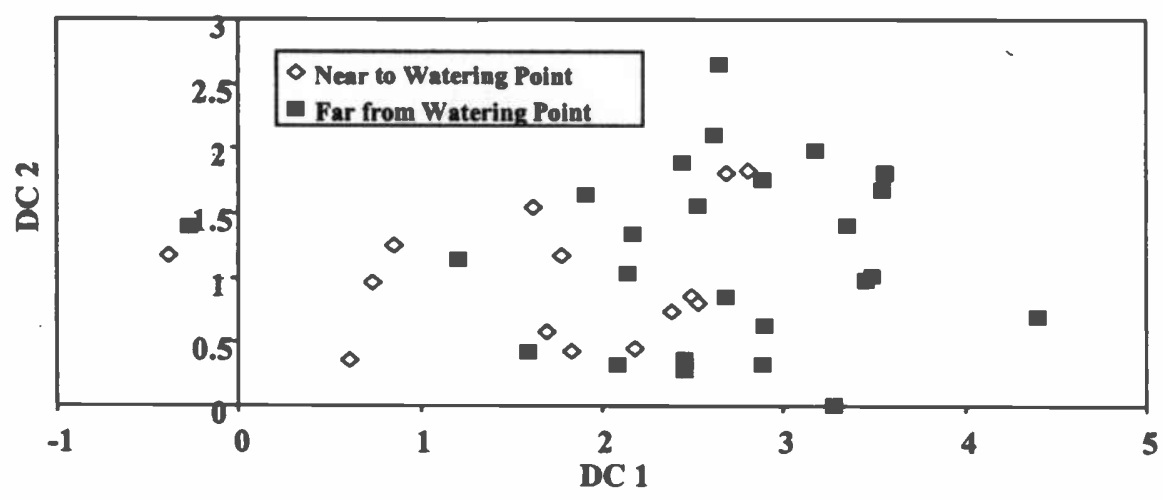

Fig. 6. Detrended correspondence analysis of plots near and far from water on Quabis, Tweespruit and Changans. Each point indicates a plot.

between mean grass height per ranch and 1996-1997 seasonal rainfall $(r=0.70, F=$ $27.796, \mathrm{P}<0.001$, error d.f. $=29$ ).

\section{Effects of short-term and medium- term grazing}

We tested for the effects of short-term and mean medium-term stocking density on mean grass height on the $\mathbf{3 1}$ farms in the large-scale study. We regressed the residuals from the above-mentioned grass height: mean annual rainfall regression on these stocking densities. We used mean annual rainfall rather than seasonal rainfall because the coefficient of determination was higher in the regression on mean annual rainfall (see above). There was no significant effect of either current $(F=0.715, P=0.405$, error d.f. $=29$ ) or medium-term stocking density $(F=0.383, P=0.541$, error d.f. $=$ 29) on grass height residuals.

\section{Management options}

\section{Stocking densities in different years} on Quabis, Tweespruit and

\section{Changans}

We calculated the geometric mean \pm S.E. stocking density for Quabis, Tweespruit and Changans for each of the 3 years on the basis of the "biomass" concept of grazing capacity using data for grass production at the end of the wet season (Bester 1995). Calculated stocking density ranged from $603.51 \mathrm{ha} / \mathrm{LSU}$ (=LSU) at one site to $13.82 \mathrm{ha} / \mathrm{LSU}$, with a mean \pm S.E. of $77.426 \pm 17.971 \mathrm{ha} / \mathrm{LSU}$ (c.v. $=0.66)($ Fig. $7 \mathrm{a}-7 \mathrm{c})$. These stocking densities are considerably lower than the recommended stocking density for this region of 18-24 ha/LSU (cited by Van der Merwe 1983). These results (Fig. 7a-7c) emphasize the extreme spatial and temporal variability in stocking densities, even on a small spatial scale. We also calculated the relationship between the coefficient of variation in calculated stocking density and the cumulative number of sites at which it was calculated (Fig. 8). The point at which an asymptote is reached indicates the minimum number of sites at which it is necessary to measure grass biomass to estimate the stocking density of a ranch using the "biomass" concept. Five (1995-1996 season) to 7 sites (1996-1997 and 1997-1998 seasons) are necessary to calculate stocking density (Fig. 8).

\section{Timing of grazing}

In a Nested ANOVA (sites nested within ranch), there was a highly significant difference among treatments $(F=27.868$, $P<0.001$, error d.f. $=1177$ ) and between ranches $(\mathrm{F}=16.041, \mathrm{P}<0.001)$ in the grass-clipping experiment. Using Scheffe's post hoc tests, we found that the significant difference among treatments was only due to the significant difference between the control and the other 2 treatments (wet and dry season clips). Mean \pm S.E. grass height in the control plots was $4.940 \pm 0.410 \mathrm{~cm}$, in the dry season clipping plots was $2.041 \pm 0.215 \mathrm{~cm}$, and in the wet season clipping plots was $2.653 \pm$ $0.230 \mathrm{~cm}$ (Fig. 9). Thus, the amount of clipping but not the timing of clipping influences mean grass height.

\section{Mountain vs. plains differences in grass biomass}

There was no significant difference in grass biomass between mountain $(7.5 \pm$ $\left.1.0 \mathrm{~g} / \mathrm{m}^{2}\right)$ and plain sites $\left(6.8 \pm 1.7 \mathrm{~g} / \mathrm{m}^{2}\right)$ in either March $1996(\mathrm{t}=0.370, \mathrm{P}=$ 0.715 , d.f. $=22)$ or in March $1997(t=$ $1.605, \mathrm{P}=0.126$, d.f. $=22$; mountain $=$ $28.7 \pm 1.8 \mathrm{~g} / \mathrm{m}^{2}$, plains $=21.7 \pm 4.0 \mathrm{~g} / \mathrm{m}^{2}$ ). However, in March 1998, grass biomass was significantly higher in mountain (33.9 $\left.+2.2 \mathrm{~g} / \mathrm{m}^{2}\right)$ than in plains sites $(19.3 \pm 2.2$ $\left.\mathrm{g} / \mathrm{m}^{2}\right)(\mathrm{t}=4.781, \mathrm{P}<0.001$, d.f. $=22)$. 


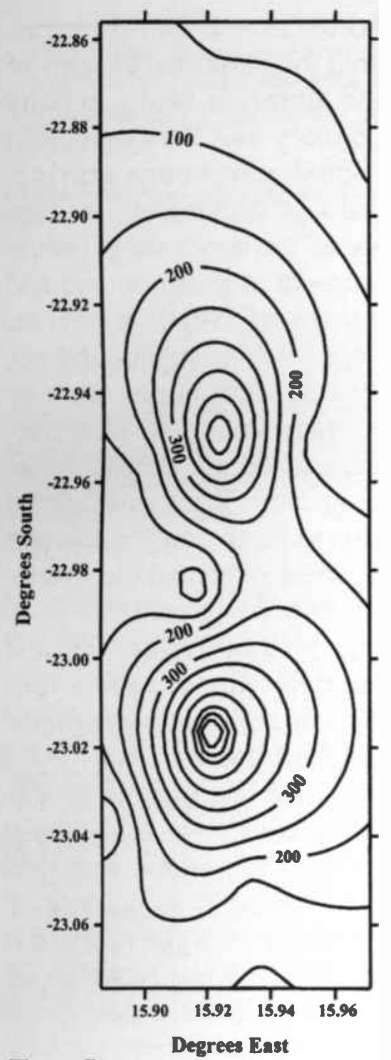

Figure 7a

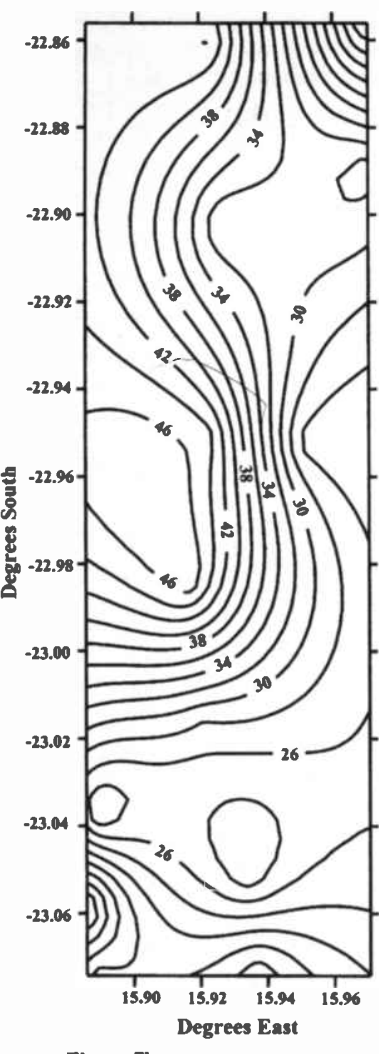

Figure 7b

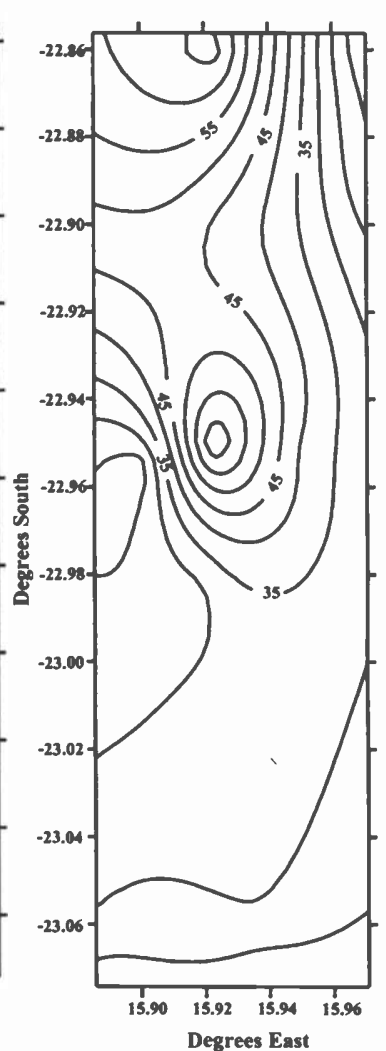

Figure $7 c$

rainfall fit this criterion and in 22 of these years the low seasonal rainfall criterion was fulfilled (i.e. $82 \%$ of years). This percentage is significantly greater than parity $\left(\chi^{2}=10.704, P>0.01\right.$, d.f. $\left.=1\right)$.

\section{Discussion}

Our results indicate the over-riding importance of rainfall on grass production in Namibia, as has been found in several other arid ecosystems (e.g. Ellis and Swift 1988, Ward and Olsvig-Whittaker 1993, Ward et al. 1993, Ward et al. 1998). At a large spatial scale, rainfall variation appears to be the only important factor, and over-rides the effects of grazing, at least in the short to medium term (Ward and Ngairorue 2000). The significant negative correlation between c.v. and median annual rainfall indicates that the effects of grazing are likely to be less important as mean annual rainfall declines. However, this is not to say that there is no effect of grazing. Ward and Ngairorue (2000) have shown that grass production along this gradient is half the amount that it was 50 years ago (Walter 1939). Ward et al. (2000b) have also shown that grazing may have important negative effects, but only if sustained in the longer term (see also Wiegand and Milton 1996). Our localscale study also showed that grazing can have a significant negative impact on vegetation, as seen in: (a) our comparison of grass inside and outside exclosures, (b) in the significant differences in grass biomass and vegetation composition near and far from watering points, and (c) the significantly greater grass height on control plots than those grazed in either wet/dry season. Indeed, in the comparison of sites near and far from watering points, grazing had a stronger effect than altitude on vegetation composition (which acts via its interaction with rainfall).

\section{Timing of grazing and moving}

\section{animals}

There are conflicting opinions and data on the effects of the timing of grazing and the period of rest after drought on plant biodiversity. It has widely been observed that plants require a period of rest after drought and heavy grazing (e.g. Danckwerts and Stuart-Hill 1987, Danckwerts 1993, Van der Heyden and Stock 1995). In ecosystems where plants are not allowed to recover, land degradation may occur as quickly as in ecosystems where stocking rates are 5-10 times as high but plants are allowed to recover. 


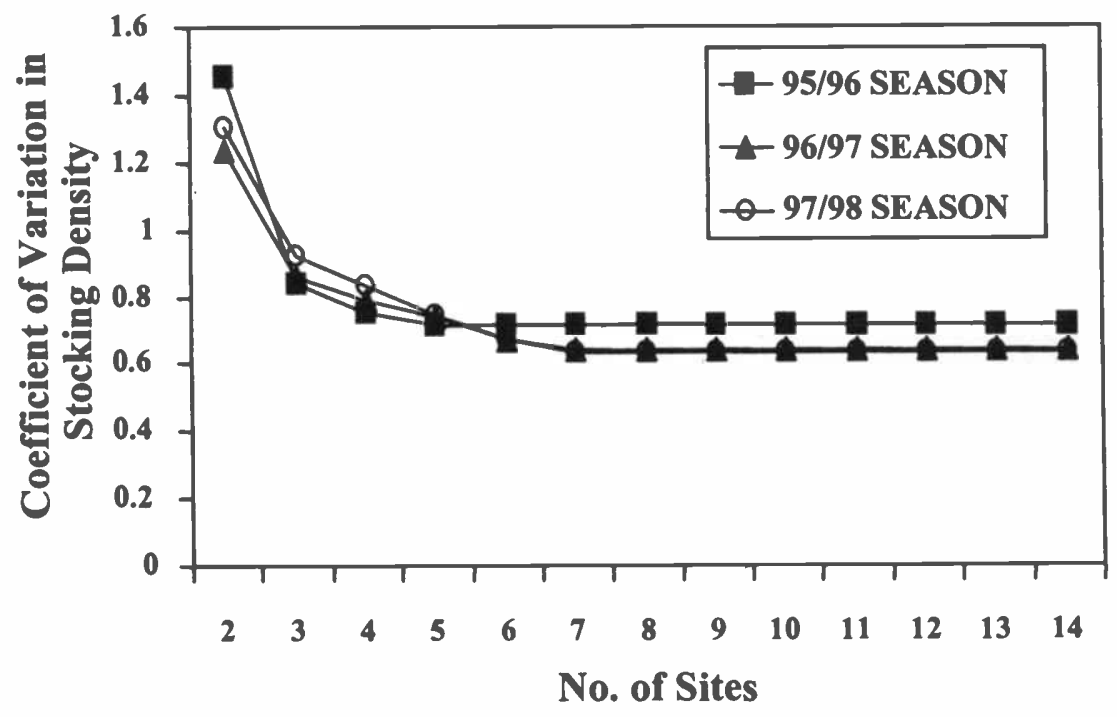

Fig. 8. Coefficient of variation in calculated stocking densities in three seasons plotted against cumulative number of sites at which grass biomass was measured. Mean minimum $( \pm S$.E. $)$ distance between pairs of sites was $3.1 \pm 0.2 \mathrm{~km}$. The asymptotic value of 5-7 sites indicates the minimum number of sites required to reliably calculate mean stocking density by the "biomass" method.

This may be one reason why comparisons of the effects of commercial and communal ranching seldom show large differences in impacts on vegetation in spite of far higher mean stocking rates on communal ranches (Archer et al. 1989, Tapson 1993, Ward et al. 1998, 2000a, 2000b). Commercial ranchers, such as those in this study, can usually afford to restock their lands soon after drought-induced mortality (or supplement forage to minimize mortality), and do not allow the vegetation time to recover lost resources. Communal ranchers, on the other hand, can seldom afford to restock and thus must allow their herds to enlarge through natural reproduction, much in the way that wild herbivore populations recover after drought-induced mortality (Ellis and Swift 1988). During herd regrowth, stocking rates are well below capacity, allowing the plants to recover lost resources. Indeed, the degradation of the Sahel of North Africa is now considered to be a result of the settlement of pastoralists and the provision of supplementary feed during drought periods, resulting in increased stock survival and greater depletion of plant resources during the post-drought recovery phase (Mainguet 1991, Sinclair and Fryxell 1985).

In marked contrast to the above-mentioned studies, many studies comparing continuous and rotational grazing have found that the period of rest after grazing had little independent effect on biodiversity and plant cover in semi-arid and arid systems above that induced by differences in stocking density (e.g. Denny and Steyn

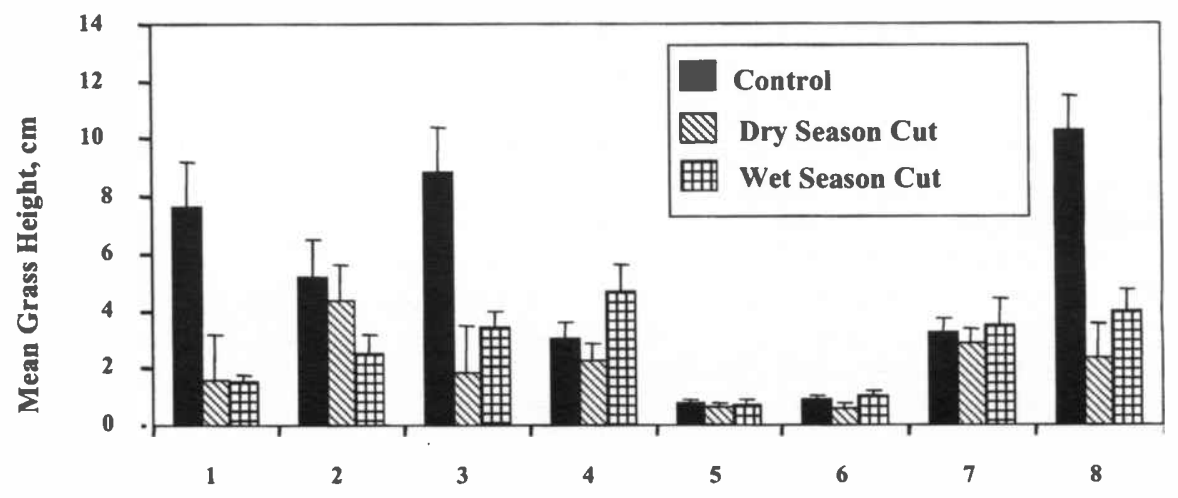

Plot Number

Fig. 9. Mean \pm S.E. grass height in control and wet-season and dry-season clipped plots on Quabis (plots 1-4) and Changans (plots 5-8) in September 1998.
1978, O'Connor 1985). Bryant et al. (1989) compared the purported benefits of rotational short-duration heavy grazing described by Savory and Parsons (1980) with conventional continuous grazing. They found that this stocking system produced no positive influence on germination or establishment of plants in arid and semi-arid regions of North America. Furthermore, this stocking regime did not improve range condition at the same or higher stocking rates compared with continuous grazing, and did not increase grass or forb standing crop. They considered stocking density to be the only important factor affecting plant cover and biodiversity. Nonetheless, they recognized that grazing systems that provide plants with rest periods are the only way to restore root reserves and replenish photosynthetic material (Bryant et al. 1989).

Our results indicate that there is no single appropriate spatial scale for moving animals (Fig. 4). Furthermore, there was no significant difference in the amount of grass on wet-season and dry-season plots. Thus, animals should be moved on an ad hoc basis to wherever there is most grass. These results indicate that a multi-paddock system not particularly crucial (contra Savory and Parsons 1980, Danckwerts and Stuart-Hill 1987, Danckwerts 1993, Bester 1995). However, we note that there are significant negative effects of keeping animals in a single region of a ranch; vegetation density and composition was negatively affected in sites near to watering points relative to those further away. Thus, movements of animals should be designed with the purpose of minimizing damage near these watering points, rather than considering whether it is the wet season or not.

The strong positive correlations of grass and rain with altitude indicate that there are some reliable features of the environment that can be used as rules of thumb for moving animals. However, the fact that grass biomass was higher in the mountains than on the plains in only 1 year in 3 indicates that factors other than altitude minimize the reliability of altitude as a guide to grass availability.

\section{Stocking densities}

Our results (Fig. 7a-7c) for stocking densities based on the "biomass" concept emphasize the extreme spatial and temporal variability in stocking densities in arid Namibia, even on a small spatial scale (Fig. 7a-7c). Furthermore, they emphasize the inappropriateness of calculating stocking densities on the basis of the mean relationship between grass biomass and mean 
Table 1. Probability of drought over an entire rainfall season (September-April) if the early season (September-December) was dry. The number of years in which September-December rainfall was low (i.e. below the $95 \%$ confidence limit of the mean) and the number of those years in which the entire season was also low (i.e. below $95 \%$ confidence limit of the seasonal mean) are recorded.

\begin{tabular}{lccccc}
\hline \hline Site & $\begin{array}{c}\text { First year } \\
\text { of data }\end{array}$ & $\begin{array}{c}\text { Years of } \\
\text { data }\end{array}$ & $\begin{array}{c}\text { Years } \\
\text { Sep-Dec had } \\
\text { low rainfall }\end{array}$ & $\begin{array}{c}\text { Years entire } \\
\text { season also } \\
\text { had low } \\
\text { rainfall }\end{array}$ & $\begin{array}{c}\% \text { years } \\
\text { early and } \\
\text { entire season } \\
\text { had low } \\
\text { rainfall }\end{array}$ \\
\hline Otjiwarongo (north) & 1907 & (years) & (years) & (years) & $(\%)$ \\
Windhoek (central) & 1890 & 106 & 22 & 13 & 59 \\
Otjimbingwe (central) & 1913 & 77 & 41 & 30 & 59 \\
Keetmanshoop (south) & 1948 & 47 & 31 & 26 & 61 \\
\hline
\end{tabular}

long-term rainfall. Furthermore, because the mean and the variance in rainfall are negatively correlated, stocking density should not be calculated for a range of mean rainfall isohyets (e.g. between $100-200 \mathrm{~mm}$ ) as is currently done (Van der Merwe 1983). Our calculations and results suggest a more appropriate way to calculate stocking densities: establish a grid of raingauges across the ranch, with an inter-gauge distance of about $3 \mathrm{~km}$. At the end of March (end of the grass growing season) at each gauge, randomly throw a $1 \mathrm{~m}^{2}$ frame at least 8 times and cut, dry and weigh the grass within the frame. Calculate the mean grass biomass from at least 7 sites (the point at which the asympotic c.v. is reached - Fig. 8). Then calculate stocking density following the "biomass" concept as indicated above.

The results on the probability of a drought season occurring following an early dry season indicate that the current selling strategy followed by ranchers is inappropriate and unduly conservative. We suggest that ranchers sell only 10-15 $\%$ of their stock at the end of December (rather than $33 \%$ as is currently common) if the September-December rainfall is less than the lower $95 \%$ confidence limit of the long-term mean. Then, if the entire season is indeed dry, the herd size can be adjusted at the end of March following the calculations outlined above. This strategy is less conservative than the current strategy but is more closely consistent with the longterm variability in rainfall.

\section{Literature Cited}

Acocks, J.P.R. 1953. Veld types of South Africa. Mem. Bot. Surv. Sth. Afr. 28:1-192.

Archer, F.M., M.T. Hoffman, and J.E. Danckwerts, 1989. How economic are the farming units of Leliefontein, Namaqualand? J. Grassl. Soc. S. Afr. 6:211-215.
Behnke, R. and N. Abel. 1996. Revisited: the overstocking controversy in semiarid Africa. World Anim. Rev. 87:4-27.

Bester, F.V. 1995. Drought and rangeland management. p. 91-104. In: R. Moorsom, J. Franz and M. Mupotola (eds.) Coping with aridity: drought impacts and preparedness in Namibia. Brandes and Apsel/NEPRU, Frankfurt, Germany.

Bryant, F.C., B.E. Dahl, R.D. Pettit, and C.M. Britton. 1989. Does short-duration grazing work in arid and semi-arid regions ? J. Soil Water Cons. 44:290-296.

Danckwerts, J.E. 1993. Reserve carbon and photosynthesis: their role in regrowth of Themeda triandra Forsk., a widely distributed subtropical graminaceous species Funct. Ecol. 7:634-641.

Danckwerts, J.E. and G.C. Stuart-Hill. 1987. Adaptation of a decreaser and an increaser grass species to defoliation in semi-arid grassveld. J. Grassl. Soc. So. Afr. 5:218-222.

Davis, J.C. 1986. Statistics and data analysis in geology. $2^{\text {nd }}$ ed. Wiley, New York, N.Y.

Dean, W.R.J. and I.A.W. MacDonald. 1994. Historical changes in stocking rates of domestic livestock as a measure of semi-arid and arid rangeland degradation in the Cape Province, South Africa. J. Arid Environs. 26:281-298.

Denny, R.P. and J.H.S. Steyn. 1978. A comparison of continuous and rotational grazing on open granite sandveld. Ann. Rep. of the Dept. of Agr. Harare, Zimbabwe.

Ellis, J.E. and D.M. Swift. 1988. Stability of African pastoral ecosystems: alternate paradigms and implications for development. J. Range Manage. 41:450-459.

Evenari, M., L. Shanan, and N. Tadmor. 1982. The Negev: the challenge of a desert. Harvard Univ. Press, Cambridge, Mass.

Hill, M.O. and Gauch, H.G. 1980. Detrended correspondence analysis, an improved ordination technique. Vegetatio 42:47-58.

Hoffman, M.T. 1997. Human impacts on vegetation. pp. 507-534. In: R.M. Cowling, D.M. Richardson and S.M. Pierce (eds.). Vegetation of southern Africa. Cambridge Univ. Press, Cambridge, England

James, C.D., J. Landsberg, and S.R. Morton. 1999. Provision of watering points in the Australian arid zone: a review of effects on biota. J. Arid Environs. 41:87-121.
Jarman, N.G. and O.J.H. Bosch. 1973. The identification and mapping of extensive secondary invasive and degraded ecological types (test site D). pp. 77-80. In: O.G. Malan (ed.). To assess the value of satellite imagery in resource evaluation on a national scale. CSIR, Pretoria, So. Africa.

Mainguet, M. 1991. Desertification: natural background and human mismanagement. Springer-Verlag, Berlin, Germany

McAuliffe, J.R. 1990. A rapid survey method for the estimation of density and cover in desert plant communities. J. Veg. Sci. 1:653-656.

Meissner, H.H., H.S. Hofmeyr, W.J.J. Van Rensburg, and J.P. Pienaar. 1983. Classification of livestock for realistic prediction of substitution values in terms of a biologically defined large stock unit. Tech. Comm. 175. Dept. of Agr., Pretoria, So. Africa.

Middleton, N.J. and D.S.G. Thomas. 1997. World atlas of desertification. $2^{\text {nd }}$ ed. Edward Arnold, London, England.

Milchunas, D.G., W.K. Lauenroth, P.L Chapman, and K. Kazempour. 1989. Effects of grazing, topography, and precipitation on the structure of a semi-arid grassland. Vegetatio 80:11-23.

Mueller-Dombois, D. and H. Ellenberg. 1974. Aims and methods of vegetation ecology. Wiley, New York, N.Y.

O'Connor, T.G. 1985. A synthesis of field experiments concerning the grass layer in the savanna regions of southern Africa. South African Nat. Sci. Program. Rep. 114. CSIR, Pretoria, So. Africa.

Parsons, D.A.B., C.M. Shackleton, and R.J. Scholes. 1997. Changes in herbaceous layer condition under contrasting land use systems in the semi-arid lowveld, So. Africa. J. Arid Environs. 37:319-329.

Quan, J., D. Barton, and C. Conroy. 1994. A preliminary assessment of the economic impact of desertification in Namibia. Dept. of Environ. Affairs Res. Discussion Pap. No. 3, Windhoek, Namibia.

Rowland, T. 1974. The conservation ideal. The SARCCUS record for the period 1952-1970. So. African Regional Commission for the Cons. and Utiliz. of the Soil

Savory, A. and S.D. Parsons. 1973. The Savory grazing method. Rangelands 2:234-237.

Schlesinger, W., J.F. Reynolds, G.L Cunningham, L.F. Huenneke, W.M. Jarrell, R.A. Virginia, and W.G. Whitford. 1990. Biological feedbacks in global desertification. Sci. 247:1043-1048.

Scoones, I. 1995. Contrasting savanna dynamics: implications for livestock populations in Zimbabwe's dryland communal areas. p. 353-360. In: G.F. Campbell (ed.). Sustainable land management in semi-arid and subhumid regions. Proceed. of the SCOPE workshop, Dakar, Senegal. CIRAD, Montpellier, France.

Sharon, D. 1972. The spottiness of rainfall in a desert area. J. Hydrol. 17:161-175. 
Sharon, D. 1981. The distribution in space of local rainfall in the Namib Desert. J. Climatol. 1:69-75.

Sinclair, A.R.E. and J.M. Fryxell. 1985. The Sahel of Africa: ecology of a disaster. Can. J. Zool. 63:987-994.

Sullivan, S. 1996. Towards a non-equilibrium ecology: perspectives from an arid land. J. Biogeogr. 23:1-5.

Tapson, D.R. 1993. Biological sustainability in pastoral systems: The kwaZulu case. pp. 118-135. In: R.H. Behnke, I. Scoones and C. Kerven (eds.) Range ecology at disequilibrium. New models of natural variability and pastoral adaptation in African savannas. ODI/IIED/Commonwealth Secretariat, London, England.

Van der Heyden, F. and W.D. Stock. 1995. Non-structural carbohydrate allocation following different frequencies of simulation browsing in three semi-arid shrubs. Oecologia 102:238-245.

Van der Merwe, J.H. (ed.). 1983. National atlas of South West Africa. National Book Printers, Cape Town, So. Africa.
Van Schalkwyk, L.P. 1978. Veld evaluation and feed intake: studies of cattle on natural grazing. $\mathrm{PhD}$ thesis. Univ. of the Orange Free State, Bloemfontein, So. Africa. 288 pp. [In Afrikaans].

Venter, J., B. Liggitt, N.M. Tainton, and G.P.M. Clarke. 1989. The influence of different land use practices on soil erosion, herbage production, and grass species richness and diversity. J. Grassl. Soc. So. Afr. 6:89-98.

Walter, H. 1939. Grassland, Savanne und Busch der ariden Teile Afrikas in ihrer ökologischen Bedingtheit. J. wissensch. Bot. 87:750-860.

Ward, D. and B.T. Ngairorue. 2000. Are Namibia's grasslands desertifying? J. Range Manage. 53:138-144.

Ward, D. and L. Olsvig-Whittaker. 1993. Plant species diversity at the junction of two desert biogeographic zones. Biodivers. Lett. $1: 172-185$.

Ward, D., L. Olsvig-Whittaker and M.J. Lawes. 1993. Vegetation-environment relationships in a Negev desert erosion cirque. J. Veg. Sci. 4:83-94.
Ward, D., B.T. Ngairorue, A. Apollus, and J. Kathena. 2000a. Perceptions and realities of land degradation in arid Otjimbingwe, Namibia. J. Arid Environs. 45: 337-356.

Ward, D., B.T. Ngairorue, J. Karamata, and I. Kapofi. 2000b. The effects of communal and commercial pastoralism on vegetation and soils in an arid and a semi-arid region of Namibia. pp. 344-347. In: P.S. White, L. Mucina, J. Leps, and E. Van der Maarel (eds.). Vegetation science in retrospect and perspective. Opulus Press, Uppsala, Sweden.

Ward, D., B.T. Ngairorue, J. Kathena, R. Samuels, and Y. Ofran. 1998. Land degradation is not a necessary outcome of communal pastoralism in arid Namibia. J. Arid Environs. 40:357-371.

Werner, W. 1994. Land tenure issues in Namibia: interactions with sustainable resource management. p. 27-41. In: S. Wolters (ed.). Proceedings of Namibia's national workshop to combat desertification. Desert Res. Found. of Namibia, Windhoek, Namibia.

Wiegand, T. and S.J. Milton. 1996. Vegetation change in semiarid communities: simulating probabilities and time scales. Vegetatio 125:169-183. 